\title{
Study of Genetic and Phenotypic Variability among Somaclones Induced by BAP and TDZ in Micropropagated Shoot Tips of Banana (Musa spp.) Using RAPD Markers
}

\author{
Siamak Shirani Bidabadi \\ Institute of Tropical Agriculture, Universiti Putra Malaysia \\ 43400 Serdang, Selangor DarulEhsan, Malaysia \\ Tel: 603-8946-6703Ｅ-mail: smkshirani@yahoo.com
}

Sariah Meon

Institute of Tropical Agriculture, Universiti Putra Malaysia

43400 Serdang, Selangor DarulEhsan, Malaysia

Tel: 603-8946-6703 E-mail: sariahm@putra.upm.edu.my

Zakaria Wahab

Department of Crop Science, Faculty of Agriculture

Universiti Putra Malaysia, 43400 Serdang, Selangor DarulEhsan, Malaysia

Tel: 603-8946-6703Ｅ-mail: zakaria@agri.upm.edu.my

Maziah Mahmood (Corresponding author)

Department of Biochemistry, Faculty of Biotechnology and Molecular Sciences

Universiti Putra Malaysia, 43400 Serdang, Selangor DarulEhsan, Malaysia

Tel: 603-8946-6703 E-mail: maziahm@biotech.upm.edu.my

This project is financed by University Putra Malaysia, Institute of Tropical Agriculture and Department of Biochemistry, Faculty of Biotechnology and Biomolecular Sciences

\begin{abstract}
The effects of different concentrations of Benzylaminopurine (BAP) and Thidiazuron (TDZ) on somaclonal variation based on genetic and phenotypic variability among micropropagated shoot tips of banana cultivars; 'Berangan Intan', 'Berangan' and 'Rastali' were studied. With the highest concentrations of both BAP and TDZ up to $44.4 \mu \mathrm{M}$ and $7.5 \mu \mathrm{M}$, respectively, most shoots were curled and other morphological changes such as hyperhydricity and undifferentiated shoots were observed. Detectable genetic changes to reveal stable variations among 27 micropropagated variants produced by BAP and TDZ were confirmed using Random Amplified Polymorphic DNA (RAPD) markers. The percentages of polymorphism among somaclones of banana cultivars; 'Berangan Intan', 'Berangan' and 'Rastali' regenerated by TDZ were 24.4, 27.3 and 29.5, respectively which was higher than BAP treatment with the percentages of 16.7, 24.2 and 24.7, respectively. The number of scorable bands among the RAPD profiles obtained with 19 primers tested in this study varied from 6 for opa1 1 and opk03 to 18 by opc01 in somaclones derived from BAP and 4 for opk03 to 14 with opa04, opb18 and opc04 in the case of TDZ. Cluster analysis of the somaclones regenerated with each of BAP and TDZ resulted in the formation of two major groups, one belonging to Berangan Intan and Berangan (AAA) and the other to Rastali (AAB). From each dendrogram caused by BAP and TDZ, it could be concluded that regenerated somaclones by higher concentrations of both BAP and TDZ accumulated much genetic variation compared to the control and lower concentrations of each of BAP and TDZ.
\end{abstract}

Keywords: Banana, Cytokinins, RAPD, Shoot tip culture, Somaclonal Variation 


\section{Introduction}

Banana is one of the most important fruit crops as an inexpensively and easily produced source of energy providing a staple food for about 400 million people in developing countries from an area of approximately 10 million ha (Kotecha and Desai, 1996; INIBAP, 2000; FAO, 2002; Ray, 2002; Kulkarni et al., 2007; Pillay and Tripathi, 2007; OGTR, 2008; Roux et al., 2008; Bakry et al., 2009).Tissue culture causes a wide range of genetic variation as an option in plant improvement which can be combined into plant breeding programs (Jain, 1997; Rout et al., 2000; Hwang, 2004). Genetic variability generated in tissue culture process is termed as somaclonal variation (Larkin and Scowcroft, 1981; Israeli et al., 1991; Jain, 2001). Skirvin and Janick (1976) confirmed the applicable importance of somaclonal variation for horticultural plants improvement. Somaclonal variation results in the production of new genotypes with a limited change in the original genome and molecular markers such as RAPD, RFLP, AFLP and microsatellites are ideal to identify genetic and epigenetic somaclones (Jain, 2001). Somaclonal variation has been studied to assess the potential of variability among the regenerated shoots of banana cultivars (Israeli et al., 1991; Sahijram et al., 2003; Bairu et al., 2006; Harirah and Khalid, 2006; Martin et al., 2006; Ray et al., 2006; El-Dougdoug et al., 2007; Jain et al., 2007; Mohamed, 2007; Oh et al., 2007; Venkatachalam and Sreedhar, 2007; and Sheidai et al., 2008). Although somaclonal variation is undesirable in the case of micropropagation as its primary objectives is to produce true - to - type clonal planting material, it can be useful for genetic improvement of banana (Sahijram et al., 2003; and Hwang, 2004). Mohamed (2007) isolated micro - propagated variants and used RAPD markers to describe and analyses the polymorphism among them. In this study the genetic and phenotypic variations was reported among regenerated somaclones. Bairu et al. (2007) studied the effect of different types and concentrations of plant growth regulators on somaclonal variation in banana cultivar 'Cavendish'. They stated that percent of somaclonal variation increased with an increasing rate of multiplication up to $72 \%$. Sheidai et al. (2008) reported that the time - period of subculture has an increasing effect on the genetic variations induced in the regenerated banana cultivar 'Valery'. They also showed the use of RAPD molecular markers in revealing somaclonal variation in banana. Venkatachalam and Sreedhar (2007) used high levels of growth regulators during micropropagation of banana. They reported that no induced somaclonal variation caused by tissue culture conditions in banana cv. 'Nanjanagudu Rasable' (AAB) was observed in spite of exposure to high concentrations of cytokinins during micropropagation.

Considering tissue culture provides strange source of variability with a great potential in crop improvement, the objective of the present study was to assess the efficiency of TDZ and BAP at different concentrations to produce polymorphism among regenerated somaclones derived from proliferating shoot tips of banana cultivars: 'Berangan Intan', 'Berangan' and 'Rastali' using RAPD markers. Therefore, this detected somaclonal variation can be used as an in vitro culture technique for obtaining tolerant genotypes against biotic and abiotic stresses.

\section{Materials and methods}

\subsection{Tissue culture and isolation of somaclones}

Micropropagated cultures of banana; 'Berangan Intan' (AAA), 'Berangan' (AAA) and 'Rastali' (AAB) were used as the source of materials for the establishment of in vitro shoot tip cultures. The shoot apices were trimmed to a size of approximately 5 to $7 \mathrm{~mm}$ by removing several sheathing leaves and excision with minimum basal corm tissues. The shoot apices were then transferred to $100 \mathrm{ml}$ capacity conical flasks containing $30 \mathrm{ml}$ of multiplication medium. The multiplication MS medium (Murashige and Skoog, 1962) contained sucrose (30 g $\left.\mathrm{L}^{-1}\right)$, gelrite $\left(2.8 \mathrm{~g} \mathrm{~L}^{-1}\right)$ supplemented with different concentrations of benzylaminopurine (BAP) at $(0.0,11.1$, $22.2,33.3$, and $44.4 \mu \mathrm{M})$. When designing micropropagation experiments it is often necessary to have a lower concentration range for TDZ than the other cytokinins (Huetteman and Preece, 1993), therefore, the concentrations of TDZ were prepared at $(0.0,0.5,2,5$, and $7.5 \mu \mathrm{M})$. The $\mathrm{pH}$ of the medium was adjusted to 5.7 prior to autoclaving. Cultures were incubated at $26 \pm 2{ }^{\circ} \mathrm{C}$ under a $16 \mathrm{~h}$ photoperiod. Each treatment was replicated three times with each replicate having five explants. After two months of culture, phenotypic variability index was calculated according to the morphological observations in regenerated shoots by taking the ratio of abnormal to normal shoots. High phenotypic variability index values resulted in higher phenotypic variability effect of the treatments. The experiments were arranged in a completely randomized design with three replicates and the data collected were analyzed using SAS and MSTAT-C computer programs and comparison of means were tested for significance, using LSD test, at 0.05 level of probability. To determine the effect of BAP and TDZ on somaclonal variation, fresh leave samples of randomly selected shoots from each of BAP and TDZ treated 'Berangan Intan', 'Berangan' and 'Rastali' cultivars were collected at the $6^{\text {th }}$ subculture and used as a source of genomic DNA. The control samples were collected from each cultivar cultured on MS free medium. A total of 27 somaclones were sampled from all three cultivars micropropagated with BAP and TDZ at different concentrations as mentioned above and each clone was named as a number according to Tables 1 and 2. 


\subsection{Genomic DNA extraction, PCR condition and Electrophoresis}

Genomic DNA was isolated from the leaves of the parental genotypes and also from their regenerated somaclones by using DNeasy DNA extraction kit (Qiagen, Research Biolabs SDN. BHD.). The isolated DNA was loaded on $0.8 \%$ agarose gel to detect its quality. The quantity of DNA preparations was checked by spectrophotometer and the samples were diluted to concentration of $50 \mathrm{ng} \mu 1^{-1}$ and maintained at $-20^{\circ} \mathrm{C}$ for RAPD analysis. DNA amplification reactions were prepared in volumes of $25 \mu 1$ consisted of $50 \mathrm{ng}^{-1} \mathrm{l}^{-1}$ of banana genomic DNA, 10×PCR buffer (Fermentas), $200 \mu \mathrm{M}$ of dNTPs (Fermentas), $2.5 \mathrm{mM} \mathrm{MgCl}_{2}$ (Fermentas), 10 pmoles of 19 random decamer oligonucleotide primers (AccuOligo, Bioneer) from different sets (OPA, OPB, OPC, OPD, OPK, OPM and OPN) (Tables 5 and 6) and 1.25 unit of Taq DNA polymerase (Fermentas). All amplification reactions were carried out using a thermocycler (TECHNE, TC - 512) programmed for initial denaturation of $3 \mathrm{~min}$ at $95^{\circ} \mathrm{C}$ followed by 40 cycles of $30 \mathrm{sec}$ denaturation at $95^{\circ} \mathrm{C}$, primer annealing at $36^{\circ} \mathrm{C}$ for $30 \mathrm{sec}$, primer extension for $2 \mathrm{~min}$ at $72^{\circ} \mathrm{C}$ with a final extension at $72^{\circ} \mathrm{C}$ for $5 \mathrm{~min}$ and then held at $4^{\circ} \mathrm{C}$. Along with the PCR products, 100 bp DNA ladders (Fermentas and Eurx) as standard markers were subjected to electrophoresis in $1.4 \%$ agarose gel with $5 \times \mathrm{TBE}$ buffer consist of tris base $\left(\mathrm{C}_{14} \mathrm{H}_{11} \mathrm{NO}_{3}\right)$ at $54 \mathrm{~g} \mathrm{~L}^{-1}$, boric acid $\left(\mathrm{H}_{3} \mathrm{Bo}_{3}\right)$ at $27.5 \mathrm{~g} \mathrm{~L}^{-1}$, EDTA $\left(\mathrm{C}_{10} \mathrm{H}_{11} \mathrm{~N}_{2} \mathrm{O}_{8} \mathrm{Na}_{2} \cdot 2 \mathrm{H}_{2} \mathrm{O}\right)$ at $3.7 \mathrm{~g} \mathrm{~L}^{-1}$ and $\mathrm{pH} 8$, according to Muchugi et al. (2008). The gels were stained with $0.0001 \%$ ethidium bromide and visualized with UV transilluminator and photographed. DNA fragments detected after separation by electrophoresis were scored as 1 for the presence and 0 for the absence of DNA band using the software UVIDoc (version 99.02). The data obtained were subjected to PopGene (Version 1.32) software package to calculate the percentage of polymorphism between somaclones regenerated from each BAP and TDZ. Based on the band data, the similarity matrix among somaclones of banana cultivars derived from each BAP and TDZ treatments was calculated using Jaccard coefficient. Cluster analysis was carried out to construct dendrogram using SAHN module in NTSYSpc (Version 2.0.1.5, Applied Biostatistices Inc.) software package.

\section{Results and discussion}

\subsection{Phenotypic variability}

The effects of BAP and TDZ on phenotypic variability among regenerated shoots of banana cultivars 'Berangan Intan', 'Rastali' and 'Berangan' were evident after two months of culture. Phenotypic variations were observed according to the morphological characters. These various morphological features have been reported before (Israeli et al., 1991; Mohamed, 2007; Venkatachalam et al., 2007; and Strosse et al., 2008). All of visual variations were characterized as modified leaf shape and deformation or undifferentiated tissue production such as globular shapes as shown in Fig. 1. Strosse et al. (2008) similarly reported the appearance of different developmental patterns derived from banana shoot tip cultures. The morphological somaclonal variation rate varied in a wide range between 0 to $0.59,0.78$ and 0.73 for 'Berangan Intan', 'Rastali' and 'Berangan', respectively with BAP (Table 3), and 0 to $0.75,0.82$ and 0.73 for 'Berangan Intan', 'Rastali' and 'Berangan', respectively with TDZ (Table 4). There was a significant increment in variation rate between the lowest and the highest concentrations of BAP and the results indicated that the variability index among regenerated somaclones significantly increased with increasing concentration of BAP up to $44.4 \mu \mathrm{M}$ for all cultivars (Table 3), which is also generally in agreement with the findings reported by Venkatachalam et al. (2007). Martin et al. (2006) also reported the development of numerous morphological variations caused by BAP in banana cultivar 'Grande Naine' (AAA) which further supports our findings. Ray et al. (2006) reported no morphological variation among the regenerated clones during in vitro micropropagation, acclimatization and transfer to the field conditions. This contrary result could be due to application of optimum concentration of BAP $(22.2 \mu \mathrm{M})$ in the multiplication medium as previous reports (Kalimuthu et al., 2007; Venkatachalam et al., 2007; Bairu et al., 2008; and Shirani et al., 2009) and indicated that $22.2 \mu \mathrm{M}$ of BAP is the optimum cytokinin concentration for micropropagation of most banana cultivars. The main side effect of TDZ during micropropagation process is creation of morphological changes such as abnormal shoots (Huetteman and Preece, 1993). The findings of the present study showed that raising the concentration of TDZ above $2 \mu \mathrm{M}$, caused an increase in variability among regenerated shoots in most cultivars (Table 4), as the highest rate of variability was recorded with TDZ at 7.5, 5 and $2 \mu \mathrm{M}$ for 'Berangan Intan', 'Rastali' and 'Berangan', respectively (Table 4). A noticeable observation was the more irregularity effects of TDZ concentrations on the rate of variability compared to BAP (Tables 3 and 4), which could be due to cultivar dependent responses to TDZ and BAP. With the highest concentrations of both BAP and TDZ normal shoots were rarely observed and shoot tips triggered the formation of undifferentiated and globular tissues (Fig. 1). Existence of globular tissues has also been reported by Strosse et al. (2008). Although few normal shoots were formed after BAP at highest concentration, most shoots were curled and other 
morphological changes such as hyperhydricity (Fig.1a) were observed. Both BAP and TDZ at their lowest concentration significantly induced lower morphological changes (Tables 3 and 4).

\subsection{Genetic variability and molecular characterization}

In the present study the application of BAP and TDZ in high concentration induced hyperhydricity and alterations in morphology (Fig. 1). However, such morphological changes should be combined with detectable genetic changes to reveal stable variation in somaclones, therefore, the genetic variability among somaclones regenerated by different concentrations of BAP and TDZ was analyzed using RAPD molecular marker technique. The band profiles obtained by 19 primers are summarized in Tables 5 and 6 . The size of the scorable fragments ranged from 3480 - 190bp and 3400 - 140bp among somaclones derived from BAP and TDZ, respectively (Tables 5 and 6). Result of the analysis of somaclonal variation showed that there was difference between BAP and TDZ in producing genetic variation among regenerated somaclones, as in the case of BAP, the percentage of polymorphism among regenerated shoots for 'Berangan Intan', 'Berangan' and 'Rastali' was 16.7, 24.2 and 24.7, respectively (Table 5) while in case of TDZ the percentage of polymorphism was 24.4, 27.3 and 29.5 respectively (Table 6). Therefore, it was concluded that TDZ induced more frequency of polymorphism among regenerated clones than BAP in all banana cultivars tested in this study and the percentage of polymorphism also differed among banana cultivars (Tables 5 and 6). The percentage of polymorphism among banana regenerated by shoot tip culture has been reported to vary from 0 to $70 \%$ depending on genotype (Vuylsteke et al., 1991; Smith, 1998). Ray et al. (2006) showed that percentage of polymorphism by RAPD were 1.75 and 0.83 in 'Robusta' and 'Giant Governor', respectively. This significant reduction in percentage of polymorphism reported by these authors could be due to the only one concentration of BAP applied in the medium in a way that this concentration has been previously approved as optimum BAP concentration for banana micropropagation (Kalimuthu et al., 2007; Venkatachalam et al., 2007; Bairu et al., 2008; and Shirani et al., 2009) The effect of $\mathrm{BAP}$ on genetic variation has been previously reported for other cultivars of banana (Bairu et al., 2006; Martin et al., 2006; Ray et al., 2006; EL- Dougdoug et al., 2007; Mohamed, 2007; and Sheidai et al., 2008). Bairu et al. (2006) studied the correlation between multiplication rate and somaclonal variation, their results showed that treatments with high multiplication rate caused more variation. El- Dougdoug et al. (2007) recorded 25\% polymorphism among in vitro micropropagated banana which was closer to the findings reported in this study. Bairu et al. (2008) reported that BAP at $22.2 \mu \mathrm{M}$ did not have any effect on somaclonal variation and they attributed the observed somaclonal variations to factors such as number of subculture. However, a broad range of BAP concentrations $(0 \mu \mathrm{M}$ to $44.4 \mu \mathrm{M})$ applied in the present study showed the existence of polymorphism among regenerated somaclones. There are no adequate reports about the effect of TDZ on induction of genetic variability in micropropagated banana cultivars therefore, the application of TDZ and BAP separately was assessed to induce and detect genetic variability among regenerated somaclones of banana cultivars derived from each BAP and TDZ. The 19 RAPD primers selected in the present study resulted in Total of 198 and 176 scorable bands for every clone derived BAP (Table 5) and TDZ (Table 6), respectively. Out of which 33, 48 and 49 in the case of BAP and 43, 48 and 52 in the case of TDZ for 'Berangan Intan', 'Berangan' and 'Rastali', respectively were polymorphic (Tables 5 and 6). Number of scorable bands for each primer varied from 6 (opa11 and opk03) to 18 (opc01) with BAP and 4 (opk03) to 14(opa04, opb18 and opc04) in the case of TDZ (Table 5 and 6). Opk01 produced 2 polymorphic bands among the population of cultivars 'Berangan' and 'Rastali' caused by different concentrations of BAP (Table 5) which is similar to earlier report in banana (Mohamed, 2007). Opd16 produced maximum number of polymorphic bands among somaclones derived from TDZ (Table 6) in 'Berangan Intan' and 'Berangan' respectively. Similarly Jain et al. (2007) reported maximum number of polymorphic bands with opd16. Interesting observations were recorded in case of RAPD profiles obtained from primer opc01 in micropropageted shoot tips by BAP (Fig. 2) and primer opc04 in related to TDZ (Fig. 3) as an intense non - parental band was observed in line 15 for BAP and line 9 for TDZ (Figs. 2 and 3).

Regarding that genomic DNA tested in this study was extracted from the leaves of the three parental genotypes and their regenerated clones of the $6^{\text {th }}$ subculture, some parts of polymorphism recorded among the somaclones could be due to increase of the time - period of subculture, as somaclonal variation was reported to be number of subculture dependent (EL- Dougdoug et al., 2007; Bairu et al., 2008; Sheidai et al., 2008).

Cluster analysis of RAPD data for each BAP (Fig. 4) and TDZ (Fig. 5) revealed that 'Berangan Intan' (AAA) and 'Berangan' (AAA) were closer to each other than 'Rastali' (AAB) which is in agreement with the earlier study carried out between other banana genomes AAA and AAB (Ray et al., 2006). The similarity coefficient ranged from 0.27 to 0.93 among somaclones regenerated by BAP(Fig. 4) and 0.32 to 0.93 in case of TDZ (Fig. 5) from banana cultivars; 'Berangan Intan', 'Berangan' and 'Rastali'. In relation to both BAP and TDZ, two major clusters were observed (Figs. 4 and 5); one consisting of AAA genome and the other was AAB genome which 
showed least similarity. Cluster I consisted of 'Berangan Intan' and 'Berangan' (AAA) along with their somaclones and Cluster II consisted of 'Rastali' (AAB) along with its regenerated clones. In the case of BAP, somaclones 15 and 14 in AAA groups and somaclones 23 and 24 in AAB groups showed least similarity to the parental cultivars and all other regenerated somaclones (Fig. 4). Based on dendrogram caused by TDZ (Fig. 5) mother plants of AAA groups were placed together and their regenerated somaclones were placed away from their parental cultivars, as somaclone 9 from 'Berangan Intan' and somaclone 17 from 'Berangan' showed least similarity meanwhile, somaclone 28 from 'Rastali' (AAB) showed least similarity to all other. From each dendrogram caused by BAP and TDZ, it could be concluded that regenerated somaclones by higher concentrations of both BAP and TDZ accumulated much genetic variation compared to control and lower concentrations of each BAP and TDZ which supports the earlier report in banana cultivars (Bairu et al., 2006) based on positive correlation between concentration of cytokinins and frequency of genetic variation.

\section{References}

Bairu, M.W., Fennell, W. and. Staden, J.V. (2006). The effect of plant growth regulators on somaclonal variation in cavendish banana (Musa AAA cv. 'Zelig'). Scientia Horticulturae, 108: 374 - 351.

Bairu, M.W., Stirk, W.A., Dolezal, K. and Staden J.V. (2008). The role of topolins in micropropagation and somaclonal variation of banana cultivars 'Williams' and 'Grand Naine' (Musa spp. AAA). Plant Cell, Tissue and Organ Culture, 95: 373-379.

EL-Dougdoug, K.A., EL-Harthi, H.M.S., Korkar, H.M. and Taha, R.M. (2007). Detection of somaclonal variations in banana tissue culture using isozyme and DNA fingerprinting analysis. Journal of Applied Sciences Research, 3 (7): $622-627$.

Harirah, A.A. and Khalid, N. (2006). Direct Regeneration and RAPD assessment of male inflorescence derived plants of Musa acuminate cv. 'Berangan'. Asia Pacific Journal of Molecular Biology and Biotechnology, 14 (1): $11-17$.

Huetteman, C.A. and Preece, J.E. (1993). Thidiazuron: a potent cytokinin for woody plant tissue culture. Plant Cell, Tissue and Organ Culture, 33: 105-119.

Hwang, S.C. and. Ko, W.H. (2004). 'Cavendish' banana cultivars resistant to Fosarium wilt acquired through somaclonal variation in Taiwan. Plant Disease, 88: 580 - 588.

Israeli, Y., Reuveni, O. and Lahva, E. (1991). Qualitative aspects of somaclonal variations in banana propagated by in vitro techniques. Scientia Horticulturae, 48: $71-88$

Jain, P.K., Saini, M.L., Pathak, H. and Gupta, V.K. (2007). Analysis of genetic variation in different banana (Musa species) variety using random amplified polymorphic DNAs (RAPDs). African Journal of Biotechnology, 6 (17): $1987-1989$.

Jain, S.M. (1997). Creation of variability by mutation and tissue culture for improving plants. Acta Horticultuare, 447: $69-78$.

Jain, S.M. (2001). Tissue culture - derived variation in crop improvement. Euphytica, 118: 153 - 166.

Kalimuthu, K., Saravanakumar, M. and Senthilkumar, R. (2007). In vitro micropropagation of Musa sapientum L. ('Cavendish Dwarf'). African Journal of Biotechnology, 6 (9): 1106-1109.

Larkin, P.J. and Scowcroft, W.R. (1981). Somaclonal variation. A novel source of genetic variability from cell cultures for improvement. TAG Theoretical and Applied Genetics, 60: $197-214$.

Martin, K.P., Pachathundikandi, S.K., Zhang, C.L., Slater, A. and Madassery, J. (2006). RAPD analysis of variant of banana (Musa spp.) cv. 'Grand Naine' and its propagation via shoot tip culture. In vitro cellular Developmental Biology Plant, 42: 188 - 192.

Mohamed, A.E.S. (2007). Morphological and Molecular characterization of some banana micro - propagated variants. International Journal of Agriculture and Biology, 9 (5): 707 - 714.

Muchugi, A., Kadu, C., Kindt, R., Kipruto, H., Lemurt, S., Olale, K., Nyadoi, P., Dawson, I. and Jamnadass, R. (2008). Molecular markers for tropical trees. A practical guide to principals and procedures, p. 87. In I. Dawson and R. Jamnadass (Eds.), Nairobi, World Agroforestry Centre. ICRAFT Technical Manual no. 9. [Online] Available: http//www.worldagroforestry.org ISBN: $978-92-9059-225-9$.

Murashige, T. and Skoog, F. (1962). A revised medium for rapid growth and bioassays with tobacco tissue cultures. Physiologia. Plantarum, 15: 473-497. 
Oh, T.J., Cullis, M.A., Kunert, K., Engelborghs, I., Swennen, R. and Cullis, C.A. (2007). Genomic changes associated with somaclonal variation in banana (Musa spp.). Physiologia. Plantarum, 129: 766 - 774.

Ray, T., Dutta, I., Saha, P., Das, S. and Roy, S.C. (2006). Genetic stability of three economically important micropropagated banana (Musa spp.) cultivars of lower Indo-Gangetic plains, as assessed by RAPD and ISSR markers. Plant Cell, Tissue and Organ Culture, 85: 11- 21.

Rout, G.R., Samantaray, S. and Das, P. (2000). Biotechnology of the banana: a review of recent progress. Plant Biology, 2: $512-524$.

Sahijram, L., Soneji, J.R. and Bollamma, K.T. (2003). Analyzing somaclonal variation in micropropagated bananas (Musa spp.). In vitro Cellular and Developmental Biology Plant, 39: 551 - 556.

Sheidai, M., Aminpoor, H., Noormohammadi, Z. and Farahani, F. (2008). RAPD analysis of somaclonal variation in banana (Musa accuminata L.) cultivar 'Valery'. Acta Biologica Szegediensis, 52 (2): 307 - 311.

Shirani, S., Mahdavi, F. and Maziah, M. (2009). Morphological abnormality among regenerated shoots of banana and plantain (Musa spp.) after in vitro multiplication with TDZ and BAP from excised shoot-tips. African Journal of. Biotechnology, 8(21): 5755 - 5761.

Skirvin, R.M. and Janick, J. (1976). Tissue culture - induced variation in scented pelargonium spp. Journal of American Society of Horticultural Science, 101: 281 - 290.

Smith, M.K. (1998). A review of factors influencing the genetic stability of micropropagated bananas. Fruits, 43 : $219-223$.

Strosse, H., Andre, E. and Sagi, L. (2008). Adventitous shoot formation is not inherent to micropropagation of banana as it is in maize. Plant Cell, Tissue and Organ Culture, 95: $321-332$.

Venkatachalam, L., Sreedhar, R.V. and Bhagyalakshmi, N. (2007). Micropropagation in banana using high levels of cytokinins does not involve any genetic changes as revealed by RAPD and ISSR markers. Journal of Plant Growth Regulation, 51: 193 - 205.

Vuylsteke, D., Swennen, R. and De Langhe, E. (1991). Somaclonal variation in plantains (Musa spp. AAB group) derived from shoot tip culture. Fruits, 46: $429-439$.

Table 1. The name of somaclones regenerated by different concentrations of BAP in banana cultivars, (AAA) groups and $(\mathrm{AAB})$ groups

\begin{tabular}{cccc}
\hline & & $\begin{array}{c}\text { The name of regenerated } \\
\text { BAP }\end{array}$ & somaclones \\
concentration $(\mu \mathrm{M})$ & 'Berangan Intan' & $\begin{array}{c}\text { 'Berangan' } \\
(\text { AAA })\end{array}$ & $\begin{array}{c}\text { 'Rastali' } \\
\text { (AAB) }\end{array}$ \\
\cline { 2 - 4 } & 2 & 11 & 20 \\
11.1 & 3 & 12 & 21 \\
22.2 & 4 & 13 & 22 \\
33.3 & 5 & 14 & 23 \\
44.4 & 6 & 15 & 24 \\
\hline
\end{tabular}

Table 2. The name of somaclones regenerated by different concentrations of TDZ in banana cultivars, (AAA) groups and $(\mathrm{AAB})$ groups

\begin{tabular}{|c|c|c|c|}
\hline \multirow{2}{*}{$\begin{array}{c}\text { TDZ } \\
\text { concentration }(\mu \mathrm{M})\end{array}$} & \multicolumn{3}{|c|}{$\begin{array}{c}\text { The name of regenerated } \\
\text { somaclones }\end{array}$} \\
\hline & $\begin{array}{c}\text { 'Berangan Intan' } \\
\text { (AAA) }\end{array}$ & $\begin{array}{c}\text { 'Berangan' } \\
\text { (AAA) }\end{array}$ & $\begin{array}{l}\text { 'Rastali' } \\
\text { (AAB) }\end{array}$ \\
\hline 0 & 2 & 11 & 20 \\
\hline 0.5 & 7 & 16 & 25 \\
\hline 2 & 8 & 17 & 26 \\
\hline 5 & 9 & 18 & 27 \\
\hline 7.5 & 10 & 19 & 28 \\
\hline
\end{tabular}


Table 3. The effect of different concentration of BAP on phenotypic variability index among regenerated somaclones of banana cultivars

\begin{tabular}{|c|c|c|c|c|c|}
\hline Cultivar & $\begin{array}{l}\mathrm{BAP}(0 \mu \mathrm{M}) \\
\text { Control }\end{array}$ & $\mathrm{BAP}(11.1 \mu \mathrm{M})$ & $\mathrm{BAP}(22.2 \mu \mathrm{M})$ & $\operatorname{BAP}(33.3 \mu \mathrm{M})$ & $\mathrm{BAP}(44.4 \mu \mathrm{M}$ \\
\hline 'Berangan Intan' & $\mathrm{h}$ & 0.17 & 0.08 & $0.38 \mathrm{~d}$ & $0.59 \mathrm{c}$ \\
\hline ‘Rastali’' & $\mathrm{h}$ & $0.057 \mathrm{gh}$ & $0.24 \mathrm{e}$ & $0.59 \mathrm{c}$ & $0.78 \quad \mathrm{a}$ \\
\hline $\begin{array}{l}\text { 'Berangan' } \\
\operatorname{LSD}(0.05)=0.075\end{array}$ & $0 \mathrm{~h}$ & 0.1 & $0.03 \mathrm{gh}$ & $0.66 \mathrm{bc}$ & $0.73 \mathrm{ab}$ \\
\hline
\end{tabular}

Values within rows with the same letter are not significantly different at the 0.05 Probability level according the LSD test.

Table 4. The effect of different concentration of TDZ on phenotypic variability index among regenerated somaclones of banana cultivars

\begin{tabular}{|c|c|c|c|c|c|}
\hline \multirow[t]{2}{*}{ Cultivar } & $\mathrm{TDZ}(0 \mu \mathrm{M})$ & $\operatorname{TDZ}(0.5 \mu \mathrm{M})$ & $\mathrm{TDZ}(2 \mu \mathrm{M})$ & $\mathrm{TDZ}(5 \mu \mathrm{M})$ & $\operatorname{TDZ}(7.5 \mu \mathrm{M})$ \\
\hline & \multicolumn{5}{|l|}{ Control } \\
\hline 'Berangan Intan' & $0 \quad \mathrm{i}$ & $0.13 \mathrm{~h}$ & 0.24 & $0.57 \mathrm{e}$ & 0.75 \\
\hline 'Rastali' & 0 & $0.11 \mathrm{~h}$ & $0.31 \mathrm{f}$ & $0.82 \mathrm{a}$ & $0.76 \quad b$ \\
\hline 'Berangan' & 0 & 0.23 & 0.73 & $0.67 \mathrm{c}$ & $0.62 \mathrm{~d}$ \\
\hline $\operatorname{LSD}(0.05)=0.044$ & & & & & \\
\hline
\end{tabular}

Values within rows with the same letter are not significantly different at the 0.05 Probability level according the LSD test. 
Table 5. Analysis of polymorphism obtained with random primers among somaclones regenerated by different concentrations of BAP in banana cultivars; 'Berangan Intan', 'Berangan' and 'Rastali'.

\begin{tabular}{|c|c|c|c|c|c|c|c|c|c|}
\hline \multirow[t]{2}{*}{ Primer } & \multirow[t]{2}{*}{$\begin{array}{l}\text { Nucleotide } \\
\text { Sequences } \\
5^{\prime}-3^{\prime}\end{array}$} & \multirow[t]{2}{*}{$\begin{array}{c}\text { Total } \\
\text { Number of } \\
\text { bands }\end{array}$} & \multirow[t]{2}{*}{$\begin{array}{l}\text { Size range } \\
\text { (bp) }\end{array}$} & \multicolumn{3}{|c|}{$\begin{array}{l}\text { No. of } \\
\text { polymorphic } \\
\text { bands }\end{array}$} & \multicolumn{3}{|c|}{ \% Polymorphism } \\
\hline & & & & BI & B & $\mathrm{R}$ & BI & B & $\mathrm{R}^{*}$ \\
\hline ора04 & AATCGGGCTG & 13 & $2280-270$ & 4 & 7 & 4 & 30.8 & 53.8 & 30.8 \\
\hline opa11 & CAATCGCCGT & 6 & $3480-790$ & 0 & 0 & 3 & 0.0 & 0.0 & 50.0 \\
\hline opa14 & CTCGTGCTGG & 10 & $2000-190$ & 4 & 5 & 5 & 40.0 & 50.0 & 50.0 \\
\hline opa19 & CAAACGTCGG & 11 & $3100-550$ & 3 & 5 & 3 & 27.3 & 45.4 & 27.3 \\
\hline opa20 & GTTGCGATCC & 11 & $2000-370$ & 4 & 0 & 2 & 36.4 & 0.0 & 18.2 \\
\hline opb18 & CCACAGCAGT & 12 & $2060-210$ & 2 & 1 & 5 & 16.7 & 8.3 & 41.7 \\
\hline орc01 & TTCGAGCCAG & 18 & $1950-200$ & 4 & 6 & 2 & 22.2 & 33.3 & 11.1 \\
\hline opc02 & GTGAGGCGTC & 14 & $1470-220$ & 0 & 5 & 8 & 0.0 & 35.7 & 57.1 \\
\hline орc04 & CCGCATCTAC & 14 & $2140-220$ & 0 & 4 & 1 & 0.0 & 28.6 & 7.1 \\
\hline opc05 & GATGACCGCC & 10 & $2230-260$ & 2 & 1 & 2 & 20.0 & 10.0 & 20.0 \\
\hline орс07 & GTCCCGACGA & 8 & $2400-250$ & 1 & 2 & 2 & 12.5 & 25.0 & 25.0 \\
\hline орс08 & TGGACCGGTG & 8 & $2460-660$ & 2 & 2 & 0 & 25.0 & 25.0 & 0.0 \\
\hline opd 16 & AGGGCGTAAG & 8 & $1210-390$ & 2 & 2 & 4 & 25.0 & 25.0 & 50.0 \\
\hline opk01 & TGCCGAGCTG & 10 & $1410-220$ & 0 & 2 & 2 & 0.0 & 20.0 & 20.0 \\
\hline opk03 & CCCTACCGAC & 6 & $2080-440$ & 0 & 0 & 1 & 0.0 & 0.0 & 16.7 \\
\hline opm16 & GTAACCAGCC & 9 & $2050-240$ & 0 & 3 & 1 & 0.0 & 33.3 & 11.1 \\
\hline opm 20 & AGGTCTTGGG & 8 & $2000-220$ & 2 & 0 & 1 & 25.0 & 0.0 & 12.5 \\
\hline opn03 & GGTACTCCCC & 12 & $2115-220$ & 3 & 3 & 2 & 25.0 & 25.0 & 16.7 \\
\hline opn09 & TGCCGGCTTG & 10 & $2500-220$ & 0 & 0 & 1 & 0.0 & 0.0 & 10.0 \\
\hline Total & - & 198 & $3480-190$ & 33 & 48 & 49 & 16.7 & 24.2 & 24.7 \\
\hline
\end{tabular}

*R ('Rastali'), BI ('Berangan Intan') and B ('Berangan') 
Table 6. Analysis of polymorphism obtained with random primers among somaclones regenerated by different concentrations of TDZ in banana cultivars; 'Berangan Intan', 'Berangan' and 'Rastali'.

\begin{tabular}{|c|c|c|c|c|c|c|c|c|c|}
\hline \multirow[t]{2}{*}{ Primer } & \multirow[t]{2}{*}{$\begin{array}{l}\text { Nucleotide } \\
\text { Sequences } \\
5^{\prime}-3^{\prime}\end{array}$} & \multirow[t]{2}{*}{$\begin{array}{c}\text { Total } \\
\text { Number of } \\
\text { bands }\end{array}$} & \multirow[t]{2}{*}{$\begin{array}{c}\text { Size range } \\
\text { (bp) }\end{array}$} & \multicolumn{3}{|c|}{$\begin{array}{l}\text { No. of } \\
\text { polymorphic } \\
\text { bands }\end{array}$} & \multicolumn{3}{|c|}{$\%$ Polymorphism } \\
\hline & & & & $\mathrm{BI}$ & $\mathrm{B}$ & $\mathrm{R}$ & $\mathrm{BI}$ & B & $\mathrm{R}^{*}$ \\
\hline opa04 & AATCGGGCTG & 14 & $2950-280$ & 1 & 2 & 3 & 7.1 & 14.3 & 21.4 \\
\hline opa11 & CAATCGCCGT & 5 & $3180-230$ & 0 & 0 & 0 & 0.0 & 0.0 & 0.0 \\
\hline opa14 & CTCGTGCTGG & 6 & $2110-470$ & 0 & 2 & 0 & 0.0 & 28.6 & 0.0 \\
\hline opa19 & CAAACGTCGG & 7 & $1550-200$ & 5 & 0 & 4 & 71.4 & 0.0 & 57.1 \\
\hline opa20 & GTTGCGATCC & 10 & $2890-450$ & 1 & 0 & 3 & 10.0 & 0.0 & 30.0 \\
\hline opb18 & CCACAGCAGT & 14 & $3400-420$ & 3 & 5 & 4 & 21.4 & 35.7 & 28.6 \\
\hline opc01 & TTCGAGCCAG & 13 & $2110-200$ & 3 & 4 & 3 & 23.1 & 30.8 & 23.1 \\
\hline opc02 & GTGAGGCGTC & 9 & $1890-330$ & 2 & 2 & 5 & 22.2 & 22.2 & 55.6 \\
\hline opc04 & CCGCATCTAC & 14 & $2170-200$ & 5 & 4 & 1 & 35.7 & 28.6 & 7.1 \\
\hline opc05 & GATGACCGCC & 10 & $2500-310$ & 2 & 3 & 5 & 20.0 & 30.0 & 50.0 \\
\hline opc07 & GTCCCGACGA & 8 & $2000-230$ & 1 & 4 & 2 & 12.5 & 50.0 & 25.0 \\
\hline opc08 & TGGACCGGTG & 7 & $2280-460$ & 2 & 2 & 2 & 28.6 & 28.6 & 28.6 \\
\hline opd16 & AGGGCGTAAG & 11 & $2110-140$ & 5 & 6 & 2 & 45.4 & 54.5 & 18.2 \\
\hline opk01 & TGCCGAGCTG & 7 & $1800-220$ & 3 & 4 & 5 & 42.9 & 57.1 & 71.4 \\
\hline opk03 & CCCTACCGAC & 4 & $1000-370$ & 1 & 2 & 2 & 25.0 & 50.0 & 50.0 \\
\hline opm16 & GTAACCAGCC & 6 & $2050-360$ & 3 & 2 & 2 & 50.0 & 33.3 & 33.3 \\
\hline opm20 & AGGTCTTGGG & 10 & $2860-220$ & 3 & 2 & 2 & 30.0 & 20.0 & 20.0 \\
\hline opn03 & GGTACTCCCC & 8 & $2000-450$ & 3 & 4 & 3 & 37.5 & 50.0 & 37.5 \\
\hline opn09 & TGCCGGCTTG & 13 & $2500-220$ & 0 & 0 & 4 & 0.0 & 0.0 & 30.8 \\
\hline Total & - & 176 & $3400-140$ & 43 & 48 & 52 & 24.4 & 27.3 & 29.5 \\
\hline
\end{tabular}

"R ('Rastali'), BI ('Berangan Intan') and B ('Berangan') 


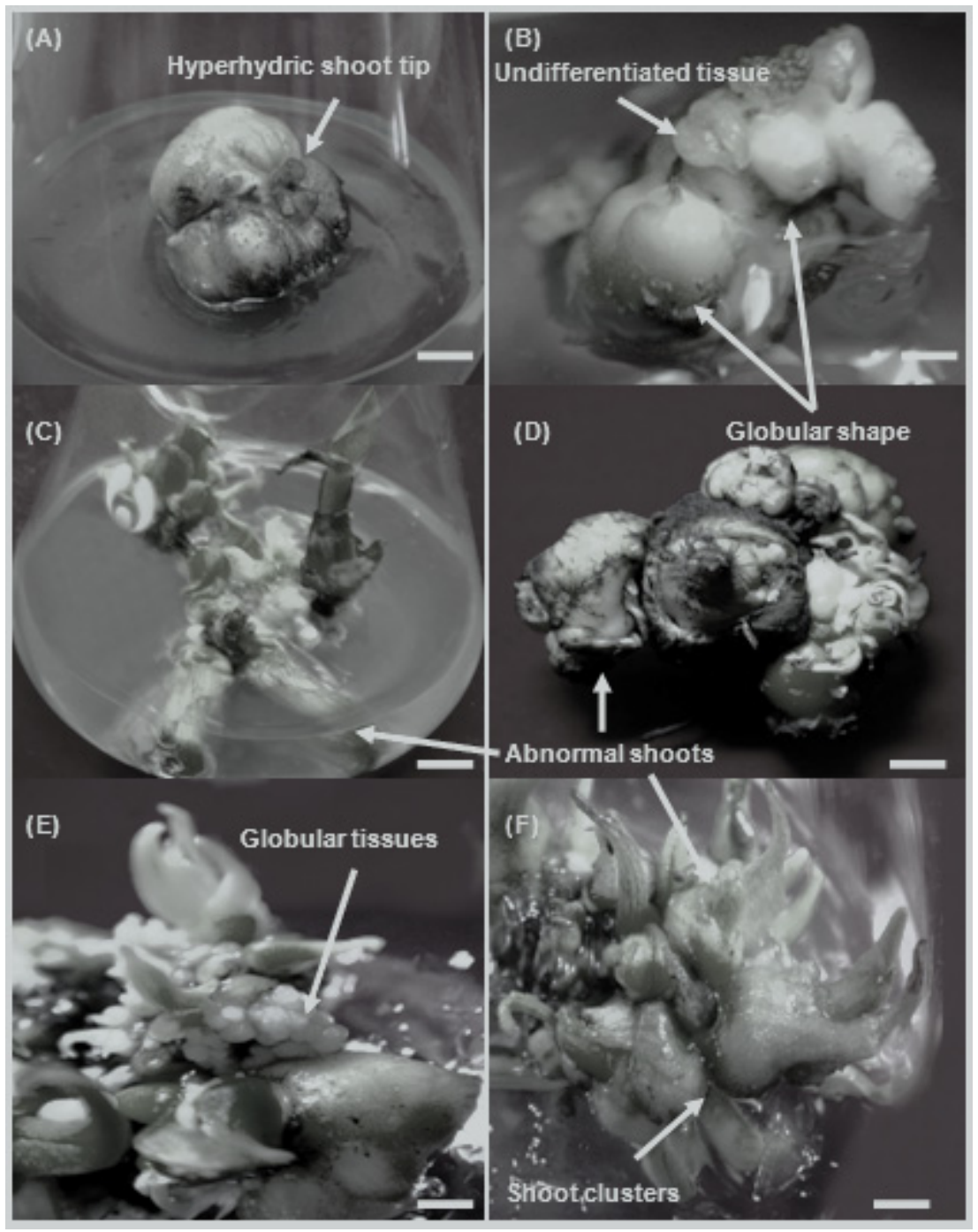

Figure 1. Morphological changes distinguished among micropropagated shoot tips on MS medium supplemented with the high concentrations of BAP and TDZ; (A) reveals hyperhydric shoot tip of cultivar 'Berangan Intan' caused by BAP at $44.4 \mu \mathrm{M}$, bar $=8 \mathrm{~mm}$; (B) and (E) present undifferentiated and globular tissues caused by TDZ at $7.5 \mu \mathrm{M}$ in cultivar 'Berangan' and $5 \mu \mathrm{M}$ in cultivar 'Berangan Intan' respectively, bar $=4 \mathrm{~mm}$; (C) shows abnormal shoot regeneration in cultivar 'Rastali' by $33.3 \mu \mathrm{M}$ of BAP, bar $=10 \mathrm{~mm}$; (D) and (F) show proliferated shoot tips by TDZ at $7.5 \mu \mathrm{M}$ in cultivar 'Rastali' and BAP at 33.3 in cultivar 'Berangan' respectively, bar $=5 \mathrm{~mm}$. 
(A)

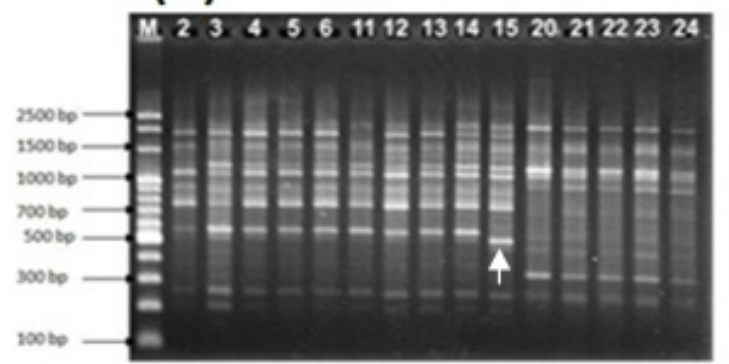

(C)

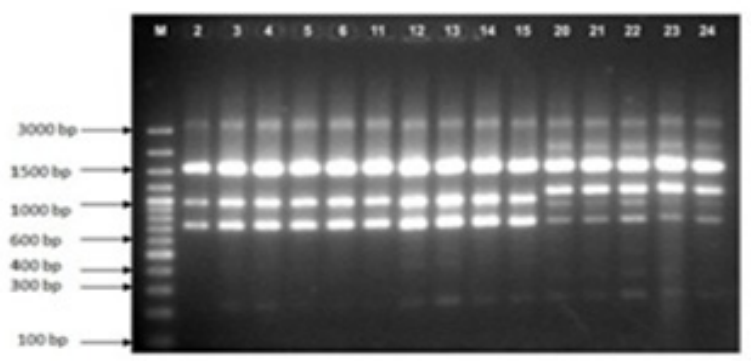

(B)

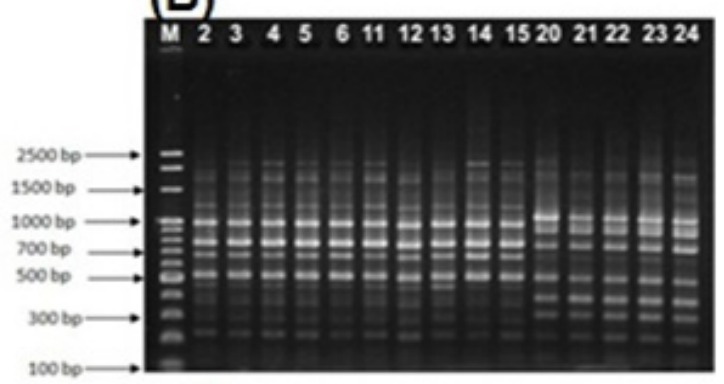

(D)

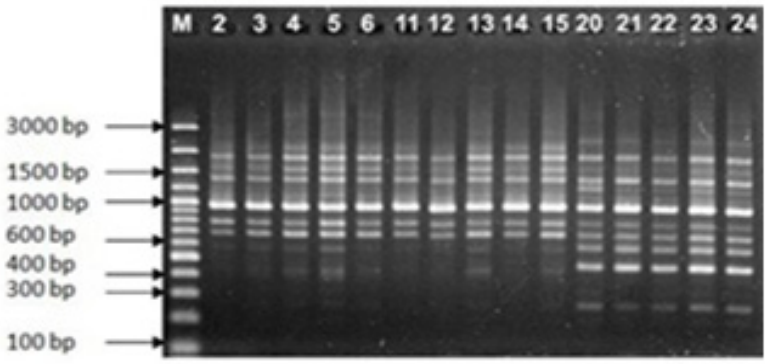

Figure 2. RAPD profiles A, B, C and D generated by opc01, opc04, opa11 and opn03 primers respectively for parental banana cultivars: 'Berangan Intan', 'Berangan' and 'Rastali' as lanes 2, 11 and 20 respectively and regenerated somaclones caused by different concentrations of BAP according to Table 1.

(A)
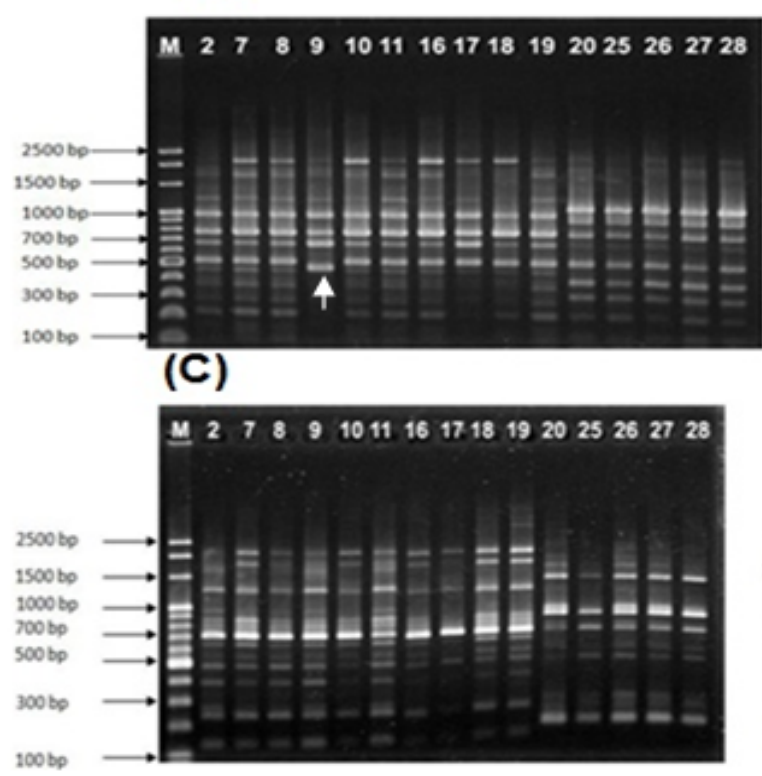

(B)

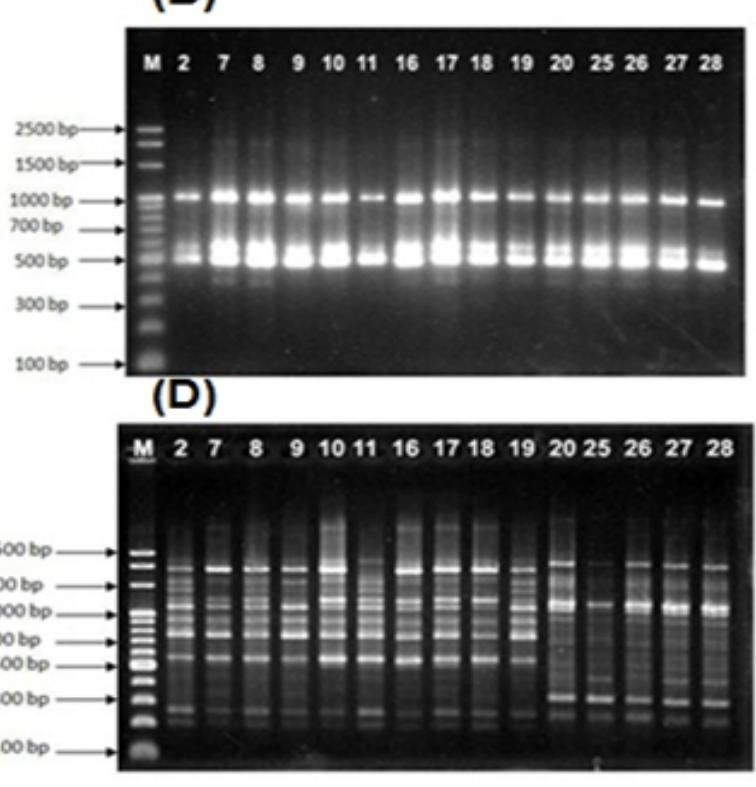

Figure 3. RAPD profiles A, B, C and D generated by opc04, opk03, opd16 and opc01 primers respectively for parental banana cultivars: 'Berangan Intan', 'Berangan' and 'Rastali' as lane 2, 11 and 20 respectively and regenerated somaclones caused by different concentrations of TDZ according to Table 2 . 


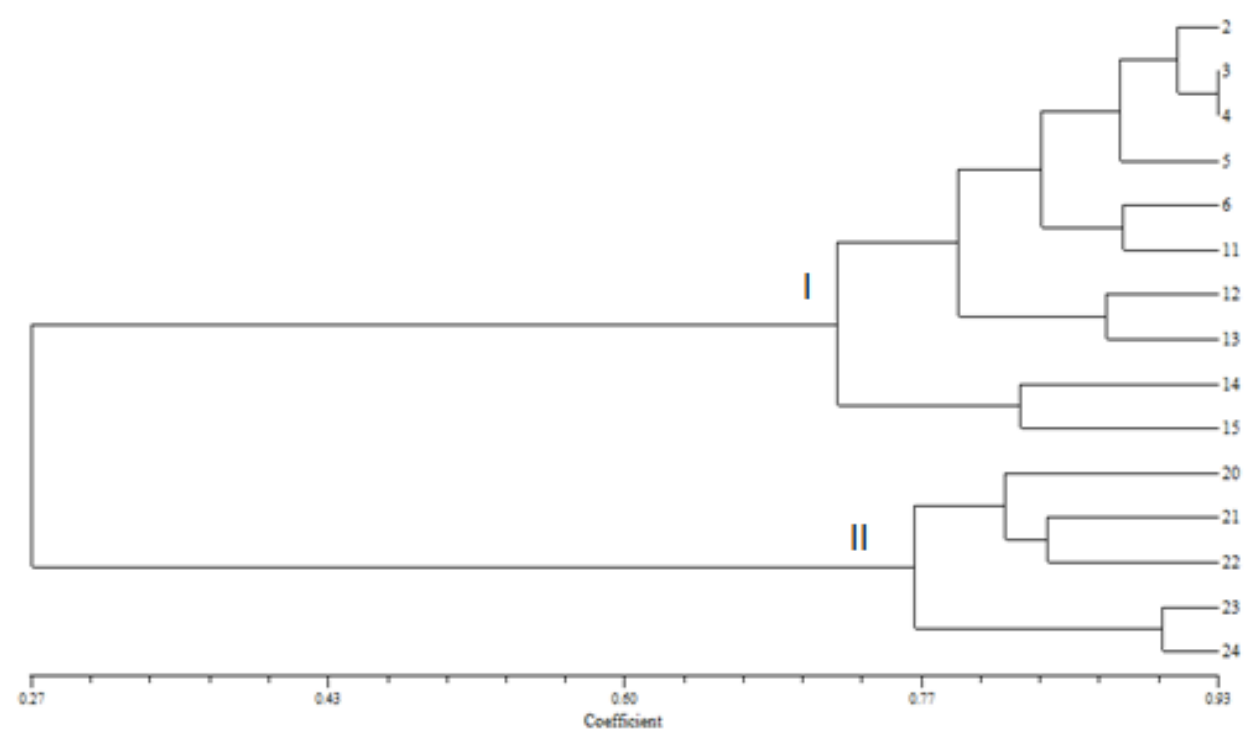

Figure 4. RAPD dendrogram based on the Jaccard similarity coefficient, showing the genetic distance between parental plants and somaclones regenerated by different concentrations of BAP. 2, 11 and 20 are parental plants (controls) and 3, 4, 5, 6, 12, 13, 14, 15, 21, 22, 23 and 24 are micropropagated somaclones of cultivars 'Berangan Intan', 'Berangan' and 'Rastali' respectively according to Table 1.

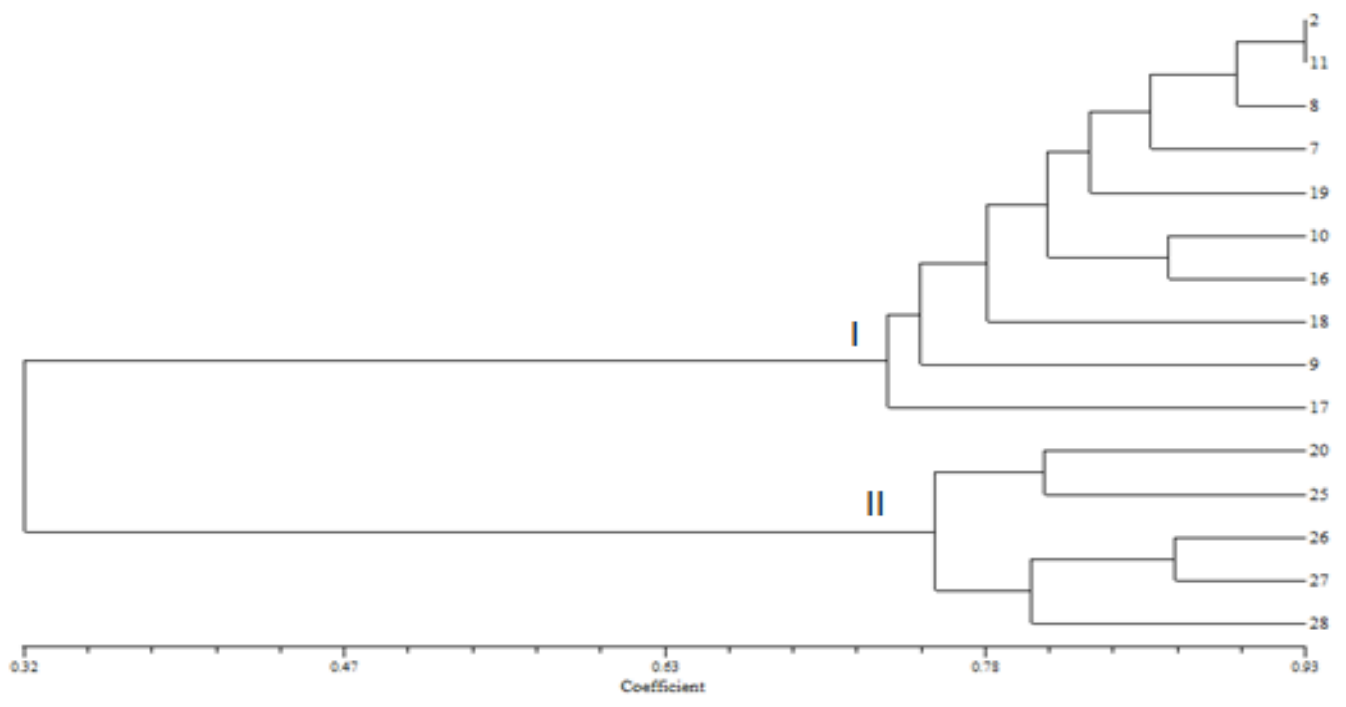

Figure 5. RAPD dendrogram based on the Jaccard similarity coefficient, showing the genetic distance between parental plants and somaclones regenerated by different concentrations of TDZ. 2, 11 and 20 are parental plants (controls) and 7, 8, 9, 10, 16, 17, 18, 19, 25, 26, 27 and 28 are micropropagated somaclones of cultivars 'Berangan Intan', 'Berangan' and 'Rastali' respectively according to Table 2. 